\title{
The Effects of Public Enterprise Management Evaluation on Business Performance: Focusing on the Incheon International Airport Corporation
}

\author{
Yung-Kil Lee ${ }^{1}$, Ki-Woong Kim ${ }^{1} \&$ Jin-Woo, Park ${ }^{1}$ \\ ${ }^{1}$ Department of Business Administration, Korea Aerospace University, South Korea \\ Correspondence: Jin-Woo, Park, Associate Professor, Department of Business Administration, Korea Aerospace \\ University 200-1, Hwajeon-dong, Deokyang-gu, Goyang-si, Gyeonggi-do, 421-791, South Korea. Tel: \\ 82-2-300-0354. E-mail: jwpark@kau.ac.kr
}

Received: August 30, 2013

Accepted: September 18, 2013

Online Published: October 28, 2013

doi:10.5539/ibr.v6n11p192

URL: http://dx.doi.org/10.5539/ibr.v6n11p192

\begin{abstract}
This paper seeks to investigate the cause-effect relationships between public enterprise management evaluation and the improvement of business performance. For this study, a research model was proposed by applying the principal-agent theory and path analysis of the structural equation model with maximum likelihood estimator was applied to data collected from 312 employees at the Incheon International Airport Corporation (IIAC). The results revealed that the influential factors suggested in the current study explained $68.03 \%$ of the business performance, which represents a high explanatory value. The influential factors, mediation variable, and moderation variable that are indicated in this study predicted the cause-effect relationships between the business performance of the airport enterprise and other variables. This study provides insights for a new possibility of observation from the perspective of an airport enterprise and public enterprise management evaluation.
\end{abstract}

Keywords: airport, business performance, evaluation, moderator, mediator

\section{Introduction}

The Incheon International Airport Corporation (IIAC) has been growing at a remarkable pace, sustaining strong business practices, and helping Korea further its development. By the year 2017, over one million passengers and ten million ton will be transported through IIAC. It is believed that IIAC's successful achievements and its potential will provide opportunities to extend its businesses and increase the amount of employment in the near future. Therefore, there is a need to better understand the improvement of IIAC's business performance as a public airport enterprise.

The purpose of this study is to examine the cause-effect relationships between public enterprise management evaluation and airport enterprise business performance and to provide implications and insights for the growth and development of the airport enterprise. Previous studies on public enterprise management evaluation have mostly used secondary data to investigate evaluation systems from the evaluator's perspective. However, less attention has been given to the need for research from the performer's perspective, which comes from current employees. Therefore, it is important to investigate the cause-effect relationship between public enterprise management evaluation and business performance by conducting an empirical study using survey data collected from employees at the airport enterprise.

This study proposes to answer four research questions as follows. First, what theory does this study intend to extend? Second, is the mediation effect of public enterprise management evaluation statistically significant? Third, is the moderation effect of the incentives resulting from public enterprise management evaluation statistically significant for the improvement of airport enterprise business performance? Fourth, how well do influential factors for airport enterprise business performance explain business performance? In order to answer these questions, the principal-agent theory as a conceptual model is discussed next.

\section{Conceptual Background}

The proposed conceptual model is presented in Figure 1. The conceptual model considers four factors. Two internal factors-leadership and system - and two external factors - public enterprise management evaluation 
and incentive - are proposed. The proposed conceptual model presents leadership as an internal factor for business performance and performance management system as an external factor. In addition, the conceptual model presents public enterprise business management evaluation as a mediator and incentives as a moderator.

The conceptual model is based on a review of previous research that looked at the principal-agent theory, public enterprise management evaluation, leadership, performance management systems, public enterprise management evaluation, incentives, and business performance. The following review presents an overview of the related literature that led the present authors to the development of the conceptual model.

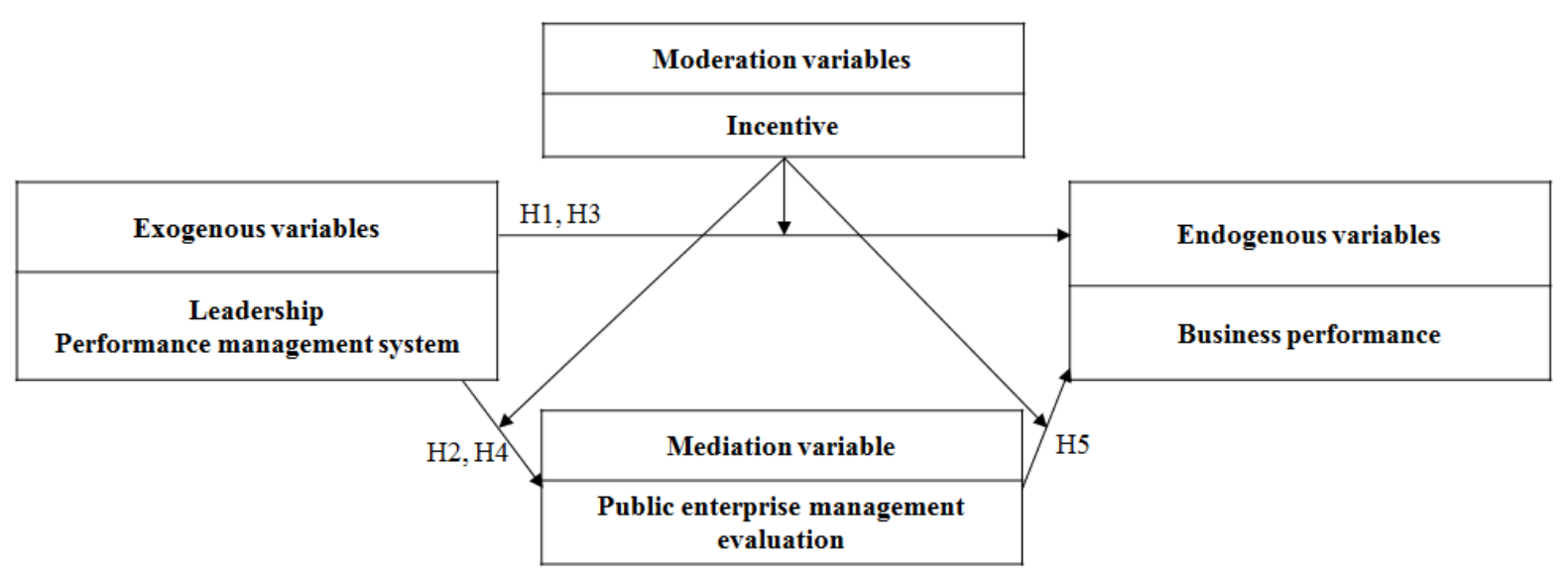

Figure 1. Proposed conceptual model

\subsection{Principal-Agent Theory}

The principal-agent theory applies neoclassical economic behavioral theory to cooperative organizations. For example, if a government/congress is a principal and a cooperative organization that provides services on behalf of the government/congress plays the role of an agent, the original information about services and costs associated with the services offered by the cooperative organization belong to the agent. In this respect, the principal and agent may share asymmetric information. Such asymmetry of information may cause ineffectiveness, resulting from imperfect motivation and outcome. According to the principal-agent theory, benefits take place when the principal strengthens its control over the agent. Specifically, the principal operating the agent performance management includes financial management, consumer and user management, and business management for the national management reinforcement (Vickers \& Yarrow, 1988). Based on the principal-agent theory the main goals of performance management are to solve outcome-centered effectiveness and information unbalance, which includes artificial, competitive work environment, incentive system, and performance orientated personnel management.

\subsection{Public Enterprise Management Evaluation}

Research on public enterprise management evaluation has focused on the scientific management system since the beginning of the $20^{\text {th }}$ century in the United States. Performance measurement and performance management have been investigated in an effort to improve organizational efficiency and responsibility in the public sector since the 1980s (Kravchuk \& Schack, 1996). As the outcome-centered government innovation movement increased in the 1990s, the performance management system was developed (Robert, 1997). In this system, outcomes are the primary topic for public enterprise research (Lynn et al., 2000). According to Orville (1971), when it comes to government activity, evaluation is perceived as essential for the management process. Jones (1982) emphasizes that the business performance evaluation system results in many problems with respect to public enterprises in the diverse conditions that appear from country to country. Business or resources investigated in organizations have been used to measure the efficiency and responsibility of the public sector (Hatry, 1999; Behn, 2003; Kathryn, 1997). As more attention has been put on the public sector, there has been a greater need for the attainment of transparency regarding the public sector and the effective use of natural resources. In other words, public enterprise business performance evaluation is considered as an important means for public sector business management. 


\subsection{Leadership}

The needs of consumers have become diverse in the digital era of the $21^{\text {st }}$ century. In order to operate in this business environment, leadership that guides the organization to the right path is required. According to Koontz and O'Donnell (1980), leadership exerts influence on others to reach corporate goals. Davis and Luthans (1979) highlight that leadership affects activities including ordering employee tasks and demanding performance, as well as motivating employees in order to effectively achieve the organization's goals. Leadership implies that a leader attentively manages performance (Davenport, 1998). According to Wilson (2000), leadership suggests a future direction and vision for the cooperative organization, creates a work environment where all organizational members achieve their goals, and actively participates in activities to improve business performance. Based on the previous studies, the following hypotheses are proposed:

H1: Leadership has a positive effect on business performance.

H2: Leadership has a positive effect on public enterprise management evaluation.

\subsection{Performance Management Systems}

A performance management system refers to a management system that improves organizational and employee performance to maximize the ultimate goals and business performance of a cooperative organization. A performance management system is used as a means to securing the dominant position for competition as well as to confirm and evaluate the completive position (Glendinging, 2002). Williams (2002) notes that a performance management system consists of stages such as plan, implementation, evaluation, and feedback, of which many scholars consider to be the common characteristics of a performance management system. When organizational members carry out a plan, monitoring and adequate coaching should be secured (Fahnestock, 1984). Roger (1990) insists that the process of a performance management system needs to be planned out by linking to the management evaluation procedure and incentive system. That is, a performance management system includes establishing the goals and performance criteria about organizational policy and recourse, evaluating the performance objectively on a regular basis, and linking individual performance and organizational performance to an incentive system. Based on the previous studies suggesting that a performance management system is influential for business performance and public enterprise management evaluation, the following hypotheses are proposed:

H3: A performance management system has a positive effect on business performance.

H4: A performance management system has a positive effect on public enterprise management evaluation.

\subsection{Public Enterprise Management Evaluation}

According to Kim (2001), as part of a public enterprise performance evaluation, leadership and the performance management system should be reinforced to increase efforts and motivate behavioral changes for the improvement of business performance. Park (2006) reports that introducing the management performance evaluation of government-investigated institutions results in increases on public enterprise management task and organizational competency. Kwak's (2003) research on a public enterprise management evaluation system reveals that promotion of management innovation, management efficiency, and organizational productivity are influential factors for business performance. Although it is not easy to find empirical studies on public enterprise management evaluation systems from international research, similar research on public management systems can be found. From a theoretical perspective, Lynn et al. (2000) propose an analysis model to empirically test the operation performance of a public management system. They divide performance into organizational and individual levels and analyze the system of operation performance based on influential factors such as environmental, consumer, organizational structure, and manager factors. Similarly, O'Toole and Meier (1999) also discuss an analysis model for the operation performance of a public management system. On the basis of these studies, the following hypotheses are proposed:

H5: Public enterprise management evaluation has a positive effect on business performance.

H6: Public enterprise management evaluation mediates the relationship between leadership and business performance.

H7: Public enterprise management evaluation mediates the relationship between a performance management system and business performance.

\subsection{Incentives}

Incentives play a key role in motivating behavioral changes necessary for accomplishing business performance. Park (2010) argues that incentives resulting from public enterprise management evaluation function as an 
important method to secure management efficiency. Chio et al. (2008) highlight that as the management assessment compensation system increases, management evaluation scores also go up. That is, incentives play a motivational factor for performance improvement, because incentives generate employee behavioral changes necessary for public enterprise management evaluation. Incentives enhance public enterprise management evaluation and business performance. As a result of the above discussion, the following hypothesis is proposed:

H8: The moderating effect of incentives has a positive effect on the influence of business performance.

\section{Research Methodology}

\subsection{Questionnaire Design and Measurement}

A pilot test was conducted to examine the vocabulary of the recruitment letter and survey questionnaires, as well as comprehension probability for the materials. Under a researcher's supervision, 30 employees of a public airport enterprise participated in the pilot test. The participants were asked to examine the accuracy of the survey questionnaires, evaluate their comprehensive understanding of the survey, and make suggestions for improvement. Prior to the survey data collection, a minor revision was made based on the pilot test.

Multiple items were used to measure variables in the survey questionnaire. All of the survey items were created based on previous studies. Measurement included interval scales and nominal scales. A Likert scale ranging from 1 (strongly disagree) to 7 (strongly agree) was used for 19 interval scale items, except for the measure of incentives. One of the incentives measures used a nominal scale with the response option of high and low.

Table 1. Operational definition and measurement items

\begin{tabular}{|c|c|c|c|}
\hline Factor & Operational Definition & Measure Items & Reference \\
\hline \multirow[t]{4}{*}{ Leadership } & \multirow{4}{*}{$\begin{array}{l}\text { Leading the organization for business } \\
\text { performance }\end{array}$} & Taking the initiative and setting an example (LS1) & Davenport (1998) \\
\hline & & Evaluation and compensation (LS2) & Wilson (2000) \\
\hline & & Policy creditability (LS3) & Davis(1979) \\
\hline & & Expertise (LS4) & Koontz(1980) \\
\hline \multirow[t]{4}{*}{ System } & \multirow[t]{4}{*}{$\begin{array}{l}\text { System to manage and support } \\
\text { performance }\end{array}$} & $\begin{array}{l}\text { Establishing a performance management system } \\
\text { (SY1) }\end{array}$ & $\begin{array}{l}\text { Fahnestock (1984) } \\
\text { Williams (2002) }\end{array}$ \\
\hline & & Supporting performance management (SY2) & Glendinging(2002) \\
\hline & & Monitoring and feedback (SY3) & Roger(1990) \\
\hline & & Educating and training employees (SY4) & \\
\hline \multirow{5}{*}{$\begin{array}{l}\text { Public } \\
\text { Enterprise } \\
\text { Management } \\
\text { Evaluation }\end{array}$} & \multirow{5}{*}{$\begin{array}{l}\text { Level of employees' } \begin{array}{l}\text { awareness of } \\
\text { public enterprise } \\
\text { evaluation }\end{array} \\
\text { evagement }\end{array}$} & Setting plans and goals for management evaluation & Kravchuk(1996) \\
\hline & & (FD1) & Robert(1997) \\
\hline & & Effort to achieve goals for management evaluation & Lynn(2000) \\
\hline & & $\begin{array}{l}\text { Understanding of approaches to management } \\
\text { evaluation (FD3) }\end{array}$ & $\begin{array}{l}\text { Orville(1971) } \\
\text { Hatry(1999) }\end{array}$ \\
\hline & & Examination of management evaluation (FD4) & \\
\hline \multirow{6}{*}{$\begin{array}{l}\text { Business } \\
\text { Performance }\end{array}$} & \multirow{6}{*}{$\begin{array}{l}\text { Outcomes as a result of management } \\
\text { activities }\end{array}$} & Innovation and creativity for improvement (FD5) & Fahnestock (1984) \\
\hline & & Levels of awareness of performance criteria (FD6) & $\operatorname{Kim}(2001)$ \\
\hline & & Increase on profits (PE1) & Williams (2002) \\
\hline & & $\begin{array}{l}\text { Implementation of government recommended } \\
\text { policy (PE2) }\end{array}$ & \\
\hline & & Increase on productivity (PE3) & \\
\hline & & Consumers' satisfaction improvement (PE4) & \\
\hline \multirow[t]{3}{*}{ Incentives } & \multirow{3}{*}{$\begin{array}{l}\text { Performance compensation as a result } \\
\text { of public enterprise management } \\
\text { evaluation }\end{array}$} & Employees' job satisfaction (FD5) & $\operatorname{Park}(2010)$ \\
\hline & & High & Choi(2008) \\
\hline & & Low & \\
\hline
\end{tabular}


Measurement items were modified for the purpose of this study. Items for leadership and system were modified to appropriately address the context of this study. Operational definitions and measurement items are presented in Table 1.

\subsection{Survey}

To collect experimental data that allowed the research hypotheses to be tested, employees at the public airport enterprise were targeted as research participants. Based on a random sampling method, employees who received the research recruitment letter voluntarily participated in the survey. Survey questionnaires were provided in Korean language. Data was collected from March $11^{\text {th }}$ to March $25^{\text {th }}$ in 2013 . A total number of 312 survey responses were used for the analyses. The survey responses were self-reported. Participants consisted of 212 males $(67.9 \%)$ and 100 females $(32.1 \%)$, which indicate a higher participation rate of male employees. In terms of age, there were 144 employees in their thirties, which was the highest proportion (46.2\%). With regard to years of employment, 133 employees (42.6\%) reported less than 20 years of employment; this also represented the highest proportion. When it comes to years of employment in the current division, there were even distributions; less than one year $(n=76,24.4 \%)$, less than two years $(n=75,24 \%)$, less than three years $(n=67$, $21.52 \%)$, less than five years $(n=63,20.2 \%)$. Levels of work position also appeared evenly; entry-level employees $(n=67,21.5 \%)$, deputy manager $(n=80,25.6 \%)$, manager $(n=71,22.8 \%)$, deputy general manager $(\mathrm{n}=67,21.5 \%)$.

\section{Results}

\subsection{Dimensionality Test}

A dimensionality test was conducted to test the sample adequacy and exploratory factor analysis. Kaiser-Meyer-Olkin (KMO) and Barlett's sphericity test (Meyer, 2006) were employed to test sample adequacy and goodness of fit for factorial analysis. It was found that KMO was .924 and Bartlette's sphericity test was $3.517, \mathrm{p}<.000$. The results indicated that sample adequacy and the goodness of fit for factorial analysis were statistically valid. For a factor extraction, varimax rotation was employed to simplify principal component analysis and factor loadings. The criteria for the factor extraction include an eigenvalue above 1.0 and factor loadings above $0.4, \mathrm{p}<.001$. The overall pattern of rotated factor loadings suggested a four-dimensional patternas follows: "leadership" (eigenvalue $=4.329$ ), "system" (eigenvalue $=3.159$ ), "public enterprise management evaluation" (eigenvalue $=2.769$ ), and "business performance" (eigenvalue $=2.670$ ). All of the factor loadings were above 0.4, which was statistically valid (See Table 2). The cumulative distribution of the four factors was $68.03 \%$, which showed a high level of explanation in the model. Thus, each of the factors held unique explanations respectively, which avoided the issue of unidimensionality in the measurements. Results of the exploratory factor analysis and cumulative distributions of each factor are shown in Table 2.

Table 2. Dimensionality, reliability and convergent validity statistics

\begin{tabular}{|c|c|c|c|c|c|c|c|c|}
\hline $\begin{array}{l}\text { Construct (no. of } \\
\text { items) }\end{array}$ & Mean & SD & $\begin{array}{l}\text { Factor loadings } \\
\text { dimensionality } \\
\text { model (EFA) }\end{array}$ & $\begin{array}{l}\text { Factor loadings } \\
\text { measurement } \\
\text { model (CFA) }\end{array}$ & $\begin{array}{l}\text { Factor loadings } \\
\text { structural model } \\
(\mathrm{SEM})\end{array}$ & $\alpha$ & CR & AVE \\
\hline Leadership (4) & 5.74 & .76 & .69.77.72. & .75 .78 .75 .70 & .74 .76 .76 .72 & .83 & .98 & .936 \\
\hline System (4) & 5.57 & .82 & .68 .74 .73 .63 & .74 .83 .79 .75 & .74 .82 .77 .77 & .86 & .98 & .942 \\
\hline $\begin{array}{l}\text { Performed Degree } \\
\text { (6) }\end{array}$ & 5.63 & .81 & $\begin{array}{l}.64 .72 .73 .78 \\
.80 .69\end{array}$ & $\begin{array}{l}.76 .75 .78 .79 \\
.84 .77\end{array}$ & $\begin{array}{l}.78 .76 .78 .77 \\
.83 .78\end{array}$ & .90 & .98 & .944 \\
\hline Business & 6.19 & .65 & .78 .83 .77 .71 & .69 .80 .76 .71 & .64 .76 .76 .74 & .83 & .98 & .924 \\
\hline Performance (5) & & & .54 & .60 & .66 & & & \\
\hline
\end{tabular}

Note: Performed Degree: Performed Degree of Public Enterprise Management; SD: Standard Deviation; CR: Composite Reliability; AVE: Average Variance Extracted; three decimal points were rounded to two decimal points.

\subsection{Measurement Model}

A confirmatory factor analysis was employed to test the measurement model. AMOS 18.0 with the maximum likelihood estimator method was used for the measurement model. Reliability, goodness of fit for the measurement model, convergent validity, and discriminant validity were examined. Cronbach's alpha, $(\alpha)$, 
composite reliability (C.R.), and average variance extracted (AVE) were calculated (See Table 2). In terms of reliability, Cronbach's alpha of leadership $(\alpha=.833)$, system $(\alpha=.858)$, public enterprise management evaluation $(\alpha=.904)$, and business performance $(\alpha=.834)$ were above 0.8 (Nunally, 1978). These results confirmed the validity and credibility of the measurement. Second, the goodness of fit for the measurement model was confirmed based on the criteria $\left(\chi^{2}=464, \mathrm{p}=.000\right.$, d.f. $=146, \mathrm{CMIN} / \mathrm{DF}=3.183, \mathrm{RMR}=.060$, GFI: $.861, \mathrm{NFI}=.871$, IFI $=.908$, TLI: .891 , CFI: .907 , RMSEA: .084). Convergent validity was evaluated by testing composite reliability. As a result, all of the composite reliabilities were above 0.8 , which was higher than the criteria of 0.7 (Hair, 1998). Lastly, discriminant validity was examined. Discriminant validity is confirmed when the square of correlation coefficients (r2) is lower than AVE (Fornell, 1981). The results indicated that the square of correlation coefficients $(\mathrm{r}=.731, \mathrm{r} 2=.534)$ was lower than the value of AVE 0.942 , which validated the discriminant validity (See table 3). Therefore, all of the criteria for the measurement model were met (Eigenvalue $>1.0$, factor loadings $>0.4$, Cronbach's alpha $>0.8$, composite reliability $>0.7$, AVE $>0.5$ ). Based on these validations of reliability, goodness of fit for the measurement model, convergent validity, and discriminant validity, a structural model was analyzed next.

Table 3. Discriminant validity: AVEs versus cross-construct squared correlations.

\begin{tabular}{lllll}
\hline Construct & Leadership & System & Performed degree & Business performance \\
\hline Leadership & .936 & & & \\
System & .679 & .942 & .944 \\
Performed degree & .638 & .731 & .432 & .924 \\
Business performance & .484 & .453 & \\
\hline
\end{tabular}

Note: the bold score (diagonal) are the AVEs of the individual constructs, and off-diagonal scores are the squared correlations between the constructs.

\subsection{Structural Model}

The purpose of the structural model is to test the relationships between latent variables and observed variables, as well as to examine a path analysis among latent variables. The path analysis examines the research hypotheses based on the path coefficient criteria $(\mathrm{p}<.05)$. A structural equation model (SEM) with a maximum likelihood estimation method was used to conduct a path analysis and examine the research hypotheses. The various fitness indices for the proposed conceptual model indicated that the conceptual model provided an excellent fit to the data $(\mathrm{CMIN} /$ d.f. $=2.254, \mathrm{RMR}=.044, \mathrm{GFI}=.906, \mathrm{NFI}=.914, \mathrm{RFI}=.893, \mathrm{IFI}=.950, \mathrm{TLI}=.937, \mathrm{CFI}=.950$, RMSEA =.064). Based on these goodness of fit validations, research hypotheses were tested. The SEM analysis supported four of the research hypotheses- $\mathrm{H} 1, \mathrm{H} 2, \mathrm{H} 4$, and $\mathrm{H} 5$ - whereas the analysis rejected $\mathrm{H} 3$. Path coefficient information and the results of research hypothesis testing are presented in Table 4.

Table 4. Results of research hypothesis testing

\begin{tabular}{|c|c|c|c|c|c|}
\hline Hypothesis & Path & Estimate & $\mathrm{CR}$ & $\mathrm{P}$ & Result \\
\hline H1 & Leadership $\rightarrow$ Business Performance & $.152^{* * *}$ & 2.049 & .040 & Supported \\
\hline $\mathrm{H} 2$ & $\begin{array}{l}\text { Leadership } \rightarrow \text { Public Enterprise Management } \\
\text { Evaluation }\end{array}$ & $.297^{* * *}$ & 2.697 & .007 & Supported \\
\hline H3 & $\begin{array}{l}\text { Performance Management System } \rightarrow \text { Business } \\
\text { Performance }\end{array}$ & .042 & .609 & .542 & Rejected \\
\hline $\mathrm{H} 4$ & $\begin{array}{l}\text { Performance Management System } \rightarrow \text { Public } \\
\text { Enterprise Management Evaluation }\end{array}$ & $.601^{* * *}$ & 6.275 & .000 & Supported \\
\hline H5 & $\begin{array}{l}\text { Public Enterprise Management Evaluation } \rightarrow \\
\text { Business Performance }\end{array}$ & $.159^{* * *}$ & 2.399 & .016 & Supported \\
\hline
\end{tabular}




\subsection{Mediation Effect}

Although mediation variables are influential for endogenous variables, which are similar to exogenous variables, mediation variables are located between exogenous variables and endogenous variables in the path analysis model. Therefore, mediation effects refer to the direct effect of mediation variables on endogenous variables and/or the indirect effect of exogenous variables via mediation variables. The mediation effect analysis proceeds as follows. First, the goodness of fit for the model is tested. The goodness of fit of the total effect model (Model I), full mediated model (Model II), and partial mediated model (Model III) are examined. The results indicated that Models I, II, and III satisfactorily met the goodness of fit requirements (See Table 5).

Table 5. Comparisons of goodness of fit among mediation models

\begin{tabular}{ll}
\hline Model & Goodness of Fit \\
\hline Model I & $\chi^{2}=139.187, \mathrm{DF}=57, \mathrm{p}=.000, \mathrm{CMIN} / \mathrm{DF}=2.442, \mathrm{RMR}=.042, \mathrm{GFI}=.936, \mathrm{AGFI}=.898, \mathrm{NFI}=.933, \mathrm{RFI}=.908, \mathrm{IFI}=.959$, \\
& $\mathrm{TLI}=.944, \mathrm{CFI}=.959, \mathrm{RMSEA}=.068$ \\
Model II & $\chi^{2}=312.718, \mathrm{DF}=139, \mathrm{p}=.000, \mathrm{CMIN} / \mathrm{DF}=2.250, \mathrm{RMR}=.045, \mathrm{GFI}=.906, \mathrm{AGFI}=.871, \mathrm{NFI}=.913, \mathrm{RFI}=.893, \mathrm{IFI}=.950$, \\
& $\mathrm{TLI}=.938, \mathrm{CFI}=.949, \mathrm{RMSEA}=.063$ \\
Model III & $\chi^{2}=311.070, \mathrm{DF}=138, \mathrm{p}=.000, \mathrm{CMIN} / \mathrm{DF}=2.254, \mathrm{RMR}=.044, \mathrm{GFI}=.906, \mathrm{AGFI}=.871, \mathrm{NFI}=.914, \mathrm{RFI}=.893, \mathrm{IFI}=.950$, \\
& $\mathrm{TLI}=.937, \mathrm{CFI}=.950, \mathrm{RMSEA}=.064$ \\
\hline
\end{tabular}

Second, the path analysis should be in the expected direction with the statistically significant path coefficients (Holyele \& Smith, 1994). The path coefficient directions of Models I, II, and III were found to be valid (See Table 6). All of the path coefficients, except a path from performance management system to business management in Model III, were statistically significant.

Table 6. Analysis results for total effects

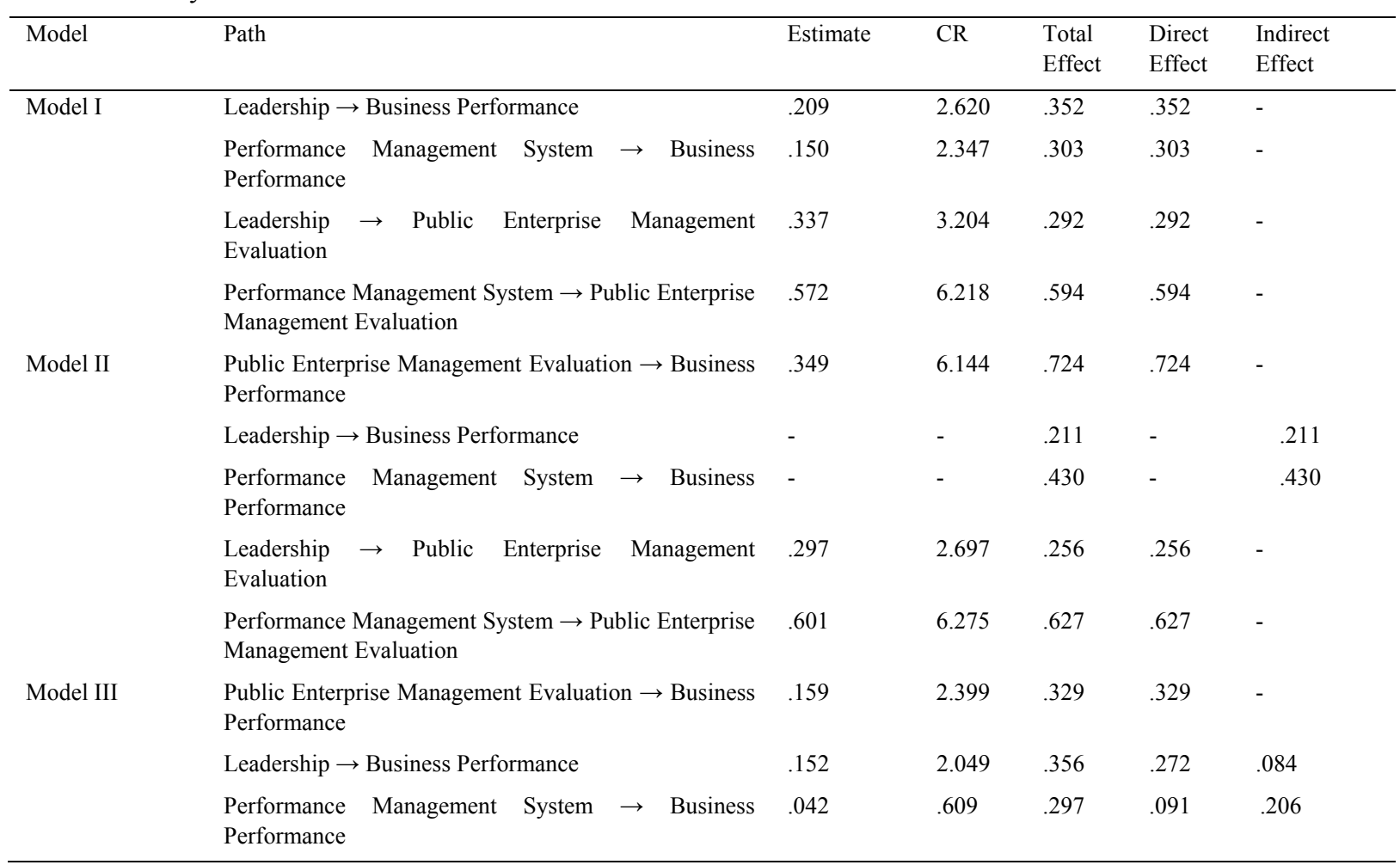

Third, the indirect effect should be statistically significant. To test the indirect effect in the present study, the bootstrapping for model comparison technique was used (Arbuckle, 2009). Indirect effects are considered statistically significant if the range between the maximum value and minimum value does not include zero for 
the indirect effects of Models II and III (Shrout \& Bolger, 2002). Public enterprise management evaluation was found to significantly mediate the relationships between leadership, performance management system, and business performance. As a result, the indirect effects were found to be statistically significant based on the findings, indicating that the range between the maximum value and minimum value did not include zero from Models II and III (See table 7).

Table 7. Analysis results for indirect effects

\begin{tabular}{lllll}
\hline Mediation Variable & Model & Path & Leadership & $\begin{array}{l}\text { Performance } \\
\text { Management System }\end{array}$ \\
\hline & Model II & Effect Size & $.211^{* * *}$ & $.430^{* * *}$ \\
& & Upper Interval & .397 & .558 \\
Public Enterprise & & Lower Interval & .054 & .266 \\
Management Evaluation & \multirow{2}{*}{ Model III } & Effect Size & .084 & .206 \\
& & Upper Interval & .255 & .492 \\
\hline
\end{tabular}

Note: ${ }^{* * *} \mathrm{p}<.01$

Fourth, to examine the full mediation and partial mediation, the difference of chi-square values between Models II and III are compared. Full mediation is found if the variation of the difference of chi-square values $\left(\Delta \chi^{2} .05(1)\right)$ between two models is below 3.841 with 1 degree of freedom and $p<.05$. Partial mediation occurs if the variation of the difference of the chi-square values $\left(\Delta \chi^{2} .05(1)\right)$ between two models is above 3.841 (Holmbeck, 1997). The variation of the difference of the chi-square values between Models II and III were below 3.841 with 1 degree of freedom and $\mathrm{p}<.05$. That is, the analysis revealed that the chi-square value of Model II was 312.718 $(\mathrm{d} . \mathrm{f} .=139, \mathrm{p}=.000)$ and the chi-square value of Model III was 311.070 (d.f. $=138, \mathrm{p}=.000)$. The variation of the difference of the chi-square values $\left(\Delta \chi^{2} .05(1)\right)$ between the two models was $1.648(p=.000)$, with 1 degree of freedom. The results indicated that the public enterprise management evaluation was fully mediated between the hypothesized relationships.

Lastly, as a result of research hypothesis testing for the mediation effect, the mediation effect of public enterprise management evaluation on the relationships between leadership, performance management system, and airport enterprise business performance were found statistically significant and fully mediated. These results showed interesting findings, because predictions of the hypothesized model were strongly supported in this study. In other words, leadership and performance management system can increase airport enterprise performance management through public enterprise management evaluation. Therefore, research hypotheses $\mathrm{H} 6$ and $\mathrm{H} 7$ were supported.

\subsection{Moderation Effect}

Considering that the effect from the causal relationship between two variables differs based on the effect size or characteristics of the third variable, moderation variables are the third variable that moderates the relationship between other two variables. In this study, the incentives resulting from public enterprise management evaluation were suggested as a moderation variable.

To test the moderation effect, this study used the analysis method developed by Jaccard and Wan (1996). The moderation effect was analyzed as follows. First, to distinguish between different groups, data using nominal scales were categorized into high and low groups. As a result, first, it was found that there were 115 individuals (36.9\%) in the high group, whereas there were 197 individuals (63.1\%) in the low group (See Table 8).

Second, research hypothesis testing for the moderation effect was conducted to analyze the two structural models. One model was freed, which did not restrict relationships among potential factors, whereas the other model was constrained by fixing relationships among potential variables equally in order to compare the difference of the chi-square values among the constraint models. It is believed that if the constraint model's variation of the difference of the chi-square values $\left(\Delta \chi^{2} .05(5)\right)$ is statistically significant to a greater degree than the chi-square criteria threshold, the research hypothesis is accepted (Matsuno et al, 2002). As a result of testing the difference of the chi-square values between the free model and constraint model, the constraint model was $\chi^{2}=681.591$ (d.f. 
$=283, \mathrm{p}=.000$ ), whereas the free model was $\chi^{2}=658.674$ (d.f. $=278, \mathrm{p}=.000$ ). The constraint model's variation of the difference of the chi-square values $\left(\Delta \chi^{2} .05(5)\right)$ was 22.917 . This result was found to be more statistically significant than the chi-square criteria threshold, $\chi^{2} .05(5)=11.070$. The finding suggested that incentives were a motivational factor for improving airport enterprise performance management. Therefore, research hypothesis H8 was supported in that the incentives resulting from public enterprise management evaluation were found to have a statistically significant moderation effect for the improvement of airport enterprise performance management. The results of research hypothesis testing for the moderation effect are presented in Table 8 and Figure 2.

Table 8. Results of research hypothesis testing for moderation effect

\begin{tabular}{|c|c|c|c|c|c|c|}
\hline \multirow{3}{*}{ Model } & \multirow{3}{*}{ Chi-square } & \multirow{3}{*}{ d.f. } & \multicolumn{3}{|c|}{ Moderation Effect } & \multirow{3}{*}{$\begin{array}{l}\text { Research } \\
\text { Hypothesis } \\
\text { Testing }\end{array}$} \\
\hline & & & $\Delta \chi^{2} .05(5)$ & $\Delta \chi_{.05(5)}^{2}$ & p-value & \\
\hline & & & \multicolumn{3}{|c|}{ Criteria Threshold Variation } & \\
\hline Constraint Model & 681.591 & 283 & 11.070 & 22.917 & .000 & \\
\hline \multirow[t]{2}{*}{ Free Model } & 658.674 & 278 & & & .000 & \\
\hline & & \multicolumn{4}{|c|}{ Moderation Variable (Incentives) } & \\
\hline \multirow{2}{*}{\multicolumn{2}{|c|}{ Path }} & \multicolumn{2}{|c|}{ High Group $(\mathrm{n}=115)$} & \multicolumn{2}{|c|}{ Low Group (n=197) } & \\
\hline & & Estimate & $\mathrm{CR}$ & Estimate & $\mathrm{CR}$ & \\
\hline \multicolumn{2}{|c|}{ Leadership $\rightarrow$ Business Performance } & .278 & $3.190^{* * *}$ & -.306 & -.901 & Supported \\
\hline \multicolumn{2}{|c|}{ Leadership $\rightarrow$ Public Enterprise Management Evaluation } & .229 & $3.302^{* * *}$ & .789 & $3.440^{* * *}$ & \\
\hline \multicolumn{7}{|c|}{$\begin{array}{lll}\text { Performance } & \text { Management } & \text { System } \\
\text { Performance } & & \end{array}$} \\
\hline \multicolumn{2}{|c|}{$\begin{array}{l}\text { Performance Management System } \rightarrow \text { Public Enterprise } \\
\text { Management Evaluation }\end{array}$} & .866 & $9.038^{* * *}$ & .191 & 1.826 & \\
\hline $\begin{array}{l}\text { Public Enterprise } \\
\text { Performance }\end{array}$ & Management Evaluation $\rightarrow$ Business & .191 & 1.520 & .466 & 1.582 & \\
\hline
\end{tabular}

Note: ${ }^{* * *} \mathrm{p}<.01$

\section{Discussion}

The present study proposes to examine the causal relationships between public enterprise management evaluation and the improvement of airport enterprise business performance. According to the current study's findings, the results were consistent with Wilson's (2002) research findings indicating that leadership creates a work environment wherein employees achieve their goals by providing a future direction and vision for the corporative organization, and a leader exerts influences on business performance by taking the lead and setting an example. These findings were also consistent with research results from Koontz and O'Donnell (1980) and Davis and Luthans (1979). Influences on achieving the corporate goals and leadership assign organizational members tasks to accomplish the organizational goals and furthermore motivate employee work performance.

Second, it was found that the direct effect of performance management system on business performance was weak. However, there was a strong effect on business performance through public enterprise management evaluation. That is, a performance management system functions as a management tool for the improvement of business performance, rather than a performance management system having a direct effect on business performance. The findings were consistent with the view held by many scholars and researchers that a performance management system is used as a management method to achieve performance. Down and Larkey (1986) and O'sborn and Gaebler (1992) perceive public enterprise management evaluation as a key component for a performance management system.

Third, the mediation effect of public enterprise management evaluation was statistically significant. In other words, leadership and a performance management system improve airport enterprise business performance through public enterprise management evaluation. The study presented very interesting 


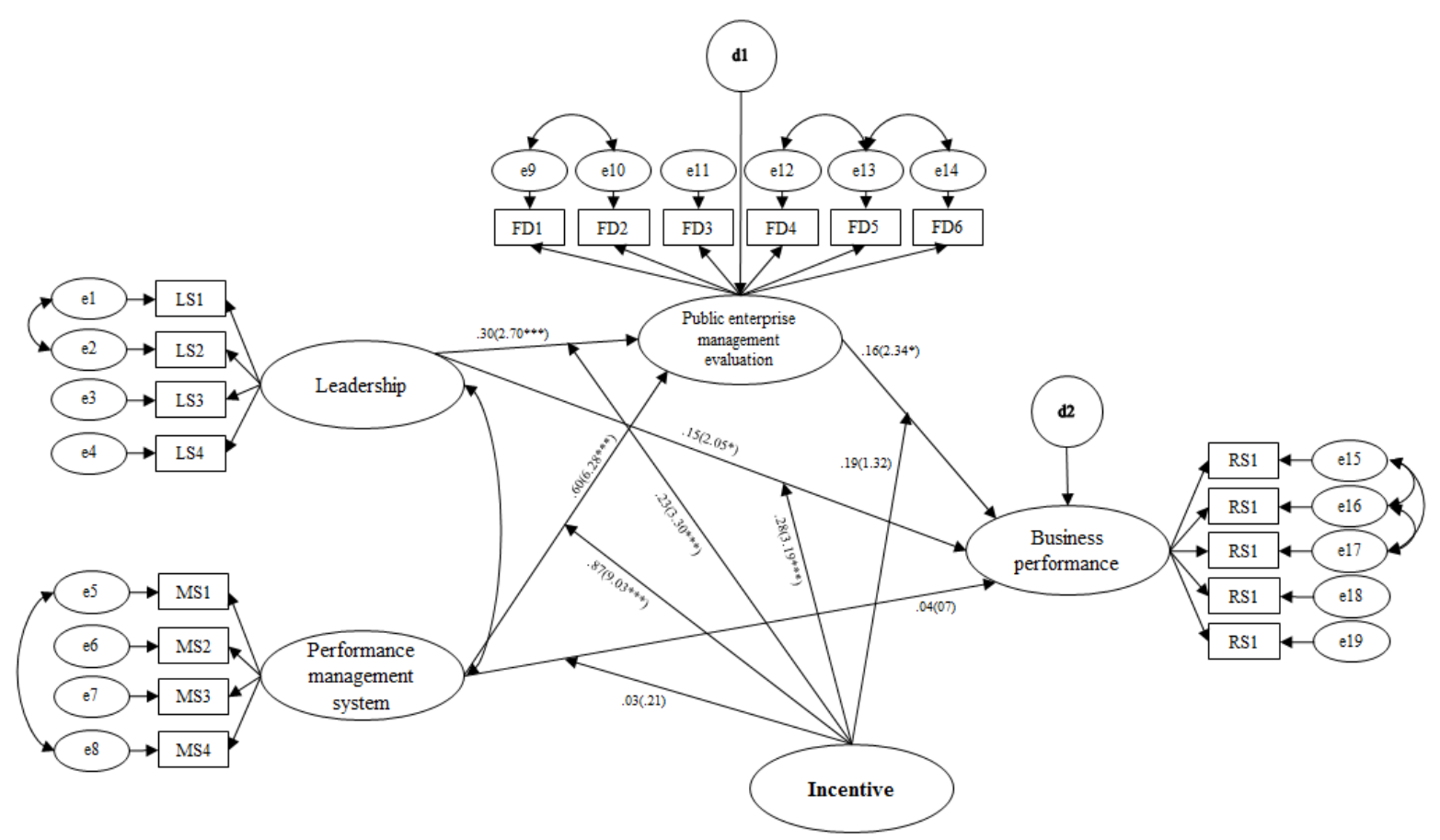

Figure 2. Paths of structural model

Note) $* \mathrm{p}<0.05, * * \mathrm{p}<0.01, * * * \mathrm{p}<0.001$; Parenthesis is C.R (Critical Ratio); Path coefficients are not standardized and three decimal points are rounded as two decimal points.

findings because the results were empirically tested. The results provide evidence for future research and further contribute to activating research on management evaluation.

Fourth, the moderation effect of incentives resulting from public enterprise management evaluation was found to be statistically significant on the relationships among leadership, performance management systems, public enterprise management evaluation, and business performance. That is, incentives motivate public enterprise management evaluation and reinforce business performance. Choi, Kim, and Jeong (2008) agreed that incentives result in behavioral changes that are necessary for business performance. Based on the discussion about the research findings, the research implications are presented next.

\section{Research Implications}

This study suggests empirical findings which indicate that airport enterprise business performance can be improved through public enterprise management evaluation. In this respect, theoretical contributions and practical implications are discussed as follows.

The current study contributes to applying the principal-agent theory to an airport enterprise. According to the principal-agent theory, the principal measures the agent business performance to secure efficiency and responsibility. If the agent performs many work tasks, rewards are given to the agent corresponding to his/her performance. If the agent does not complete business performance, s/he faces consequences. Such behavioral evidence exists through performance evaluation. The present study makes a contribution to continuing research activation on public enterprise management evaluation from the airport enterprise perspective, which has received relatively less attention. The study's findings are also valuable as theory-based empirical research data providing evidence for future research.

The present study suggests practical implications as follows. First, according to the study's findings, a leader needs to recognize the important role of leadership because it is important for managers to perform the role of leader in circumstances in which the airport enterprise requires a high level of dependence on intelligence. More investment and interest are needed to develop leadership training programs that are appropriate for airport enterprise characteristics.

Second, a performance management system has an indirect effect on business performance through public enterprise management evaluation, rather than the direct effect of performance management system on business 
performance. There is a need to educate and train organizational members with management techniques regarding performance to better understand performance management systems as a management means.

Third, creativity for innovation and improvement activity associated with public enterprise management evaluation is required. That is, it is helpful to understand the performance goals of public enterprise management evaluation, to share employees' innovative mindset, and to approach to creative task performance.

Fourth, a system is needed to objectively and fairly evaluate and reward employees based on incentives resulting from public enterprise management evaluation. In other words, the incentives play a key role to motivate behavioral changes for the improvement of task performance and business performance of public enterprise management evaluation.

\section{Conclusions}

The purpose of this study is to examine the cause-effect relationship between public enterprise management evaluation and airport enterprise business performance and to provide research implications and insights for the growth and development of the airport enterprise. First, the study's findings contribute to research activation on airport enterprises, which have received relatively less attention, by conducting empirical research on public enterprise management evaluation based on the principal-agent theory from the performer's perspective using empirical data. Second, as a result of an analysis of the mediation effect, public enterprise management evaluation was fully mediated. That is, airport enterprise business performance can be improved through public enterprise management evaluation. Third, the moderation effect of incentives resulting from public enterprise management evaluation is found to be statistically significant. In other words, the incentives motivate behavioral changes for the improvement of business performance. Fourth, influential factors significantly explain airport enterprise business performance. The hypothesized research model strongly confirms predictions of influential factors.

There exist some limitations and additional research areas for future research. This study was limited in that it was only conducted at the Incheon International Airport Corporation. Future research should explore research on management evaluation of other international airports, which differ in terms of airport management characteristics. In addition, this study limited variables to five dimensions. Using various observed variables, a multi-dimensional, empirical study needs to be conducted in the future. In spite of the limitations, the present study can be helpful for airport managers in South Korea as well as airport managers in other countries, particularly in terms of growth and development with respect to the improvement of management evaluation and business performance. The study is also useful for policy on the management evaluation of government-investigated institutions and corporative organizations.

\section{Acknowledgements}

I sincerely appreciate the cooperation from the employees at the Incheon International Airport Corporation who were willing to participate in the surveys.

\section{References}

Arbuckle, J. L. (2009). AMOS 18 User's Guide. Crawfordville, Florida: SPSS Inc.

Behn, R. D. (2003). Why Measure Performance? Different Purposes, Different Measure. Public Administration Review, 63(5), 586-606. http://dx.doi.org/10.1111/1540-6210.00322

Choi, K. J. (2008). Factors Influencing Public Agency Management Performance. Korea Association for Public Administration, 2008 Summer Conference Proceedings, No. 4.

Davenport, T., Prusak, L. (1998). Working Knowledge How Organizations Manage What They Know (pp. 123-143). Boston: Harvard Business School Press.

Davis, T. R. V., \& Luthans, F. (1979). Leadership Reexamined: A Behavior Approach. Academy of Management Review, 4(2), 237-248. http://dx.doi.org/10.5465/AMR.1979.4289022

Downs, G. W., \& Larkey, P. D. (1986). The Search for Government Efficiency: from Hubris to Helplessness. Philadelphia: Temple University Press.

Fahnestock, C. M. (1984). One Utility's System in Management Planning and Performance Review. Public Utilities Fortnightly, 114, 33-36.

Fornell, C., \& Larcker, D. F. (1981). Evaluating Structural Equation Models with Unobservable Variables and Measurement Error. Journal of Marketing Research, 18(1), 39-50. http://dx.doi.org/10.2307/3151312 
Hair, J. F., Anderson, R. E., Tatam, R. L., \& Black, W. C. (1998). Multivariate Data Analysis (5th ed.). Upper Saddle River, New Jersey: Prentice-Hall International.

Hatry, H. (1999). Performance Measurement, Getting Results. Washington, DC: Urban Institute Press.

Hatry, \& Harry. (1999). Mini-symposium on Intergovernmental Comparative Performance Data. Public Administration Review, 59(2), 101-104. http://dx.doi.org/10.2307/977629

Hoyle, R. H., \& Smith, G. T. (1994). Formulating Clinical Research Hypotheses as Structural Equation Models: A Conceptual Overview. Journal of Consulting and Clinical Psychology, 62(3), 429-440. http://dx.doi.org/10.1037/0022-006X.62.3.429

Holmbeck, G. N. (1997). Toward Terminological, Conceptual and Statistical Clarity in the Study of Mediations and Moderators: Examples From the Child-Clinical and Pediatric Psychology Literatures. Journal of Consulting and Clinical Psychology, 65(4), 599-610. http://dx.doi.org/10.1037/0022-006X.65.4.599

Jaccard, J., \& Wan, C. K. (1996). LISREL Approaches to Interaction Effects in Multiple Regression. Thousand Oaks, California: Sage.

Jones, L. P. (1982). Public Enterprise in Less-Developed Countries. Cambridge, Massachusetts: Cambridge University Press. http://dx.doi.org/10.1017/CBO9780511752988

Kathryn, E. (1997). Using performance Measurement to Improve Public and Nonprofit Programs. San Francisco: Jossey-Bass Publishers.

Kwak. (2003). The Inefficiency of the Government Investment Agency for the Control of Management Evaluation System role and Operational Performance. Public Journal, 15(1), 49-91.

Kim. (2001). Evaluation of the Public Enterprise and Internal Audit of the Connectivity. Ph.D. Dissertation, Chonnam National University.

Koontz, H., \& O'Donnell, C. (1980). Principle of Management (2nd ed.). New York: McGraw-Hill Book.

Kravchuk, R. S., \& Schack, R. W. (1996). Designing Effective Performance-Measurement Systems under the Government Performance and Results Act of 1993. Public Administration Review, 56(4), 348-358. http://dx.doi.org/10.2307/976376

Lynn, L. E., Heinrich, C. J., \& Hill, C. J. (2000). Studying Governance and Public Management: Why? How? In Heinrich, C. J., \& Lynn, L. E. (Eds.), Governance and Performance: New Perspectives (pp. 1-33). Washington, DC: Georgetown University Press.

Matsuno, K., Mentzer, J. T., \& Ozsomer, A. (2002). The Effect of Entrepreneur Proclivity and Market Orientation on Business Performance. Journal of Marketing, 66(3), 18-32. http://dx.doi.org/10.1509/jmkg.66.3.18.18507

Allen, N. J., \& Meyer, J. P. (1990). The Measurement and Antecedents of Affective, Continuance and Normative Commitment to the Organization. Journal of Occupation Psychology, 63(1), 1-18. http://dx.doi.org/10.1111/j.2044-8325.1990.tb00506.x

Nunnally, J. C. (1978). Psychometric Theory (2nd ed.). New York: McGraw-Hill.

Poland, O. F. (1971). Why does public Administration Ignore Evaluation? Public Administration Review, 31(2), 201-202.

Osborne, D., \& Gaebler, T. (1992). Reinventing Government: How the Entrepreneurial Spirit is Transforming the Public Sector. Massachusetts: Reading, Addison-Wesley.

O’Toole, L. J., \& Meier, K. J. (1999). Modeling the Impact of Public Management Implications of Structural Context. Journal of Public Administration Research and Theory, 9(4), 505-526. http://dx.doi.org/10.1093/oxfordjournals.jpart.a024421

Park. (2006). Performance Management and Organizational Capacity of the Public Sector. South Korea Secured Administration, 40(3), 219-244.

Park. (2010). Theory of Public Enterprise. Seoul: Dasan Publishers.

Roberts, A. (1997). Performance-based organization: Assessing the Gore Plan. Public Administration Review, 57(6), 465-478. http://dx.doi.org/10.2307/976958

Rogers, S. (1990). Performance Management in Local Government. Harlow, London: Longman. 
Shrout, P. E., \& Bolger, N. (2002). Mediation in Experimental and Non experimental Studies: New Procedures $\begin{array}{lllll}\text { and Recommendations. } & \text { Psychological }\end{array}$ http://dx.doi.org/10.1037//1082/989X.7.4.422

Vickers, J., \& Yarrow, G. K. (1988). Privatization: An Economic Analysis. Cambridge Massachusetts: MIT Press.

Williams, R. S. (2002). Managing Employee Performance: design and implementation in organizations. London: Thomson Learning.

Wilson, D. D., \& Collier, D. A. (2000). An Empirical Investigation of the Malcolm Baldrige Nation Quality Award Causal Model. Decision Sciences, 31(2), 361-383. http://dx.doi.org/10.1111/j.1540-5915.2000.tb01627.x

\section{Copyrights}

Copyright for this article is retained by the author(s), with first publication rights granted to the journal.

This is an open-access article distributed under the terms and conditions of the Creative Commons Attribution license (http://creativecommons.org/licenses/by/3.0/). 